\title{
Determinants of Development among Women in Manipur
}

\author{
Dr. Shougrakpam Umabati Devi \\ Teacher Education(TSG),Department of Education and Literacy,MHRD,New Delhi.
}

\section{Introduction}

The state of Manipur is situated in the north - eastern corners of India between latitude $23.83^{\circ} \mathrm{N}$ and longitude $93.03^{\circ}$ E. The state is bounded by Nagaland in the north, Cachar district of Assam in the west, Mizoram in the South and Myammar (Burma) in the South East and East. The capital of the state is Imphal, situated at an altitude of $790 \mathrm{~m}$ above mean sea level .The total geographical area of the state is $22,327 \mathrm{sq} . \mathrm{km}$ .Of this 2200 sq. Km. i.e. about $10 \%$ of the total area forms the valley surrounded by columns of lofty hills on all sides. As per Census 2011, the total population of Manipur on $1^{\text {st }}$ March 2011 is 2,570,390. The number of literates in Manipur is 1768181 according to Census 2011. The male Literacy Rate works out to 86.1 percent (Rural-83.4 percent; Urban-91.7 percent). The Female Literacy Rate works out to 72.4 percent (Rural 68.9 per cent; Urban 79.3 percent).[2]

The various people living in Manipur are:-

1. 1 Brahmins (Manipuri Hindus)

1. 2 Meiteis

1.3 Pangan (Meitei Muslim)

1.4 Tribals (Naga,Kukis etc.) and

1.5 Mayang (North Indian, South Indian, Biharis, Bengalis, Marwari's, Punjabis etc.)

In every change in the structure of the Manipur society every type of women residing in Manipur viz. Muslim, Tribal and Meitei contribute to the development of Manipur. Mrs. Grim wood also spoke of Manipur women in her book 'My three years in Manipur that "The Manipuri's do not shut up their women as is the custom in most parts of India and they are much more enlightened and intelligent in consequence". Manipuri women thus played a major role in the productive process of the state.

\section{Position of Women} political.

The position of women in Manipur's history may be studied under three heads i.e. social, economic and

\subsection{Social Conditions of women}

In Primitive period women held a very high social status in Manipur. There was equality between men and women - the latter even enjoying higher status than men. The position of women in a subordinate status has been legitimized with the coming of Hinduism in Manipur. Younger women up to the age of $35-40$ yrs are always engaged in domestic work irrespective of their class and status. School and college going girls have to do a lot of domestic work before going to classes. Women are unpaid labourers at home. The educated working women are fighting very hard in the social fields of life. They are in between tradition and modernity. They have to serve their in - laws, discharge many household duties and social obligations and working very hard not to lag behind in their offices and academic works. This period i.e from tradition to modernity may be said to be transitional but the transitional period will take at least half a generation. Thus all classes of women (educated, uneducated, richer, and poorer) are playing a great role in the social life of Manipur. There are also many social taboos for debarring women to participate in social life i.e if a pung (Mridunga) is touched by a women, it wouldn't produce any sound. In short, in spite of the varied activities and great role in social fields, the women in Manipur are not enjoying a level of equal status in society. Gender justice is evasive till the men folk restores to women, their eroded powers, rights etc.

\subsection{Economic conditions of women}

About women's economic role for example "Weaving is the second common profession which emerges out of the people's sentiments for it than for its profit which is negligible in the present context .Now a days, the economic contribution made by the educated working ladies is immense. Most of them work in government departments and in teaching profession. Of course, there are a very few women who take part in the decision making process in the family and in the society. But they are either economically better off or belong to a higher class. More than $95 \%$ of the women are either suppressed (or forced) or desire to remain inferior to man. 


\subsection{The Political women}

The role of women in Manipur politics can be viewed from three angles (1) Political attitudes such as awareness, commitment and behavior, (2) Participation in the politician process as voters and candidates in elections, and (3) Their impact on the political process of the state.

Levels of political awareness of women vary from time to time, from region to region class and community to community. From the very ancient times, Manipuri women always led non-violent and peaceful movements before men-folk used to take arms. They even corrected the injustice done by the king or by any officials of the state, by reporting the matter to the king. They were able to postpone the schedule programme of the king if the royal programme affects the interest of the state.

In the period (1819-1826) the state remained occupied by the Burmese. The Burmese army carried away and destroyed 3, 00,000 persons. In Manipur, this period is referred to as ChahiTarethKhuntakpa (Seven years of catastrophe). In that period, women took an active part in safeguarding Manipur wholeheartedly. E.W. Dun in his "Gazetter of Manipur" stated that women in Manipur during 1880 are whether married or unmarried were not confined in Zenanas as they were in Bengal or Hindustan. T.C.Hodson in his book "The Metheis" had written in 1901 that the women of Manipur hold a high and free position. Perhaps, there were gradual changes in the social system within a period of 15 years. NupiLan, women's war is an important feature of Meitei society. The first NupiLan during colonial rule occurred in 1904 when the residence of the British Political Agent was burnt down by some anti government people. In retaliation, Major Maxwell the Political Agent ordered free labour from the people to rebuild the house. Thousands of women gathered and agitated against the Government's decision. The second Nupi-lan cannot be described only as a food riot but was an expression of revolting the women against colonial oppression of revolting the women against colonial oppression and the corruption of the monarchy; December $13^{\text {th }}$ has been declared NupiShingiNumit (women's day) to dedicate to the cause of women in Manipur. It showed a deep respect for and recognition of women's collective power for the benefit of the entire society. The outbreak of the agitation was also a turning point in the emergence of new trend of political and national consciousness in the state.

Another group of local women's organization called "NishaBandh" came into existence in 1975 in Manipur in order to control the evil practice of drinking liquor by the general public in the society. In 1980, another movement was started by women in Manipur against the imposition of Armed forces special power Act 1958 and also torch bearers became very active in protesting against the atrocities of the innocent youths. The outbreak of MeiraPaibis "literally meant torch-bearer's launched purely by womenfolk of Manipur whether literate or illiterate was a new line of women's role in the social, political and economic history of Manipur. It might be considered as one of the feminist activities for the protection, preservation and development of their sons and daughters as a mother.

The women of Manipur in their participation in social, educational and economic fields could be viewed under two platforms. In one platform, the illiterate women participated controlled and occupied the market place known as Ima market (mother's market) at Khwairamband bazaar. The educated working women and the educated girls played its role through another platform. They played their role in a multi pronged approach as an economic contributors, as a working women as a resource person in the academic and social organizations as a participant in the organizations etc.

Now a day's educated working women have greater political awareness. But majority of women feel that politics has not solved the problems which affect their daily life. They are more concerned with problems which affect their day to day lives such as poverty, rising prices, unemployment, breakdown of law and order etc. [3]

\section{Conclusion}

The preliminary observations to determine women's role in economy, religions, politics and social development of Manipur are as follows-:

\subsection{Economic Role}

Women have been playing very important and significant roles in the economy of Manipur. This is true for both organized and unorganized sectors of the economy, be it agriculture, industry or services. Women have been contributing substantially and yet very often their contribution goes unnoticed by both the family and society. Women play a dual role, one as a paid worker and the other as an unpaid worker as a part of the family labour in the fields, family trade, crafts and by doing different domestic chores. Weaving, agriculture, petty businesses were the main economic resources of Meitei women. Embroidery, knitting and handicrafts are also activities engaged by women. 


\subsection{Religious Role}

Women make arrangements for offering fruits and flowers and prayers for the well being of the family. Some religious festivals require equal participation of both men and women. Such religious festivals of the Meiteis are Laiharaoba (rejoicing of God and Goddess), Cheiraoba (New Year's day), Ningol- chakouba (daughter's feast) as well as various Vaishnava festivals such as Holi, Rathjatra,Krishna-Astami, Durga-Puja and so on.

\subsection{Political Role}

Few women took active part in politics. But some were taking part against the desire of their family. They were given vote by the people according to their personal qualities. Some women were given support to stand for election when their elected husband expired.

\subsection{Social Roles}

Only a few educated employed women are able to take decisions by herself or along with her other family members. In the household decision- making, men enjoyed more power than women. To great extent men's final say determined all decisions of the household.

From the preliminary observations it can be said that women are empowered only in certain spheres. Majority of the women are from lower middle class and few are from the upper middle class. Women from the upper middle class are more empowered than from the lower middle class. Thus, class is a very important determinant for their status in the society.

\section{References}

R.K.Sapru,Women and development(Delhi: Ashish Publishing House,1989).

Directorate of Employment Exchange, Statistical Handbook of Manipur, (Government of Manipur, 2011).

Ksh.Bimola Devi, Manipuri women a study, in Sanajaoba (Ed.), Manipur Past and Present,(Delhi: Mittal Publications,1988). 